\title{
Effect of Heat Stress and Amelioration by Antioxidants on Expression Profile of Pro- and Anti-Apoptotic Genes in in vitro Matured Bovine Oocytes
}

\author{
Jafrin Ara Ahmed ${ }^{1 *}$, Nawab Nashiruddullah², Devojyoti Dutta, \\ Iftikar Hussain ${ }^{3}$, Anubha Baruah and Arup Dutta
}

${ }^{1}$ Division of Veterinary Physiology and Biochemistry, ${ }^{2}$ Division of Veterinary Pathology, Faculty of Veterinary Sciences \& Animal Husbandry, Sher-e-Kashmir University of Agricultural Sciences \& Technology-Jammu, RS Pura-181102, Jammu \& Kashmir, India

${ }^{3}$ State Biotech Hub, College of Veterinary Science, Assam Agricultural University, Guwahati-781022, Assam, India

Department of Veterinary Physiology, College of Veterinary Science, Assam Agricultural

University, Guwahati-781022, Assam, India

*Corresponding author

\section{Keywords}

Apoptosis, Bovine, Heat stress, IVM, Oocyte, Gene expression, Melatonin, Zinc

Article Info

Accepted:

18 January 2019

Available Online:

10 February 2019

\section{A B S T R A C T}

Heat stress often leads to apoptosis of oocytes through generation of free radicals. The use of antioxidants has been found to mitigate the harmful effects of these free radicals and probably apoptosis itself. The present study was conducted to evaluate the effect of heat stress on expression profile of genes related to apoptosis (pro-apoptotic Bad and Bax; and anti-apoptotic $\mathrm{Bcl}$-2) during oocyte maturation and the ameliorating effects of select antioxidants- viz. melatonin and zinc. In the experiment, bovine oocytes were divided into 4 groups and Group II, III, IV was matured under heat-stress at $41^{\circ} \mathrm{C}$. Moreover, group III and IV were supplemented with antioxidant melatonin and zinc respectively, incorporated in the oocyte maturation medium (OMM), while Group II served as antioxidant control and was matured with OMM alone. Group I served as control and was matured without heat-stress $\left(38.5^{\circ} \mathrm{C}\right)$ and antioxidant supplementation. After maturation, the total RNA was isolated for $\mathrm{Bcl}-2, \mathrm{Bax}$ and $\mathrm{Bad}$ expression. It was found that there was up regulation of $\mathrm{Bad}$ and $\mathrm{Bcl}-2$ gene expression during induced heat-stress without any supplementation (Group-II). Bax was down regulated in all groups, while Bad was down-regulated in melatonin and zinc supplemented groups. It is speculated that supplementation with zinc probably induced early maturation changes in the oocyte and induced an early meiotic arrest, which was associated with a sharp decline in all apoptosis modulator transcripts. It sis concluded that by detoxifying ROS, antioxidants may therefore subsequently reverse the ROS-induced decline in $\mathrm{Bcl}-2$ and prevent apoptosis. 


\section{Introduction}

The mechanism by which heat stress leads to a disruption in developmental competence of the oocyte remains unclear; however, one of the processes that may be involved is apoptosis, although there have been few studies on extrinsic or intrinsic control systems in reproduction for its activation (Roth and Hansen, 2004). Apoptosis is regulated by the interplay of the pro- and antiapoptotic (pro-survival) factors, involving chiefly members of the B-cell lymphoma/ leukemia 2 (BCL-2, Bcl-2) family of proteins (Youle and Strasser, 2008). All pro-apoptotic and pro-survival (anti-apoptotic) proteins belong to the Bcl-2 family (Reed et al., 1996). Bcl-2 protein counteracts Bax, and when Bax is in excess, cells execute a death command; but, when Bcl-2 dominates, the program is inhibited and cells survive. The pro or antiapoptotic activities of the Bcl-2 family members are regulated not only at the transcriptional level, but also at the posttranslational level, including phosphorylation, cleavage, translocation, and dimerization (Gross et al., 1999). Expression abundance of the Bax and Bcl-2 genes are good markers for oocyte apoptosis and subsequent embryo development (Li et al., 2009).

Bax forms a heterodimer with $\mathrm{Bcl}-2$, and functions as an apoptotic activator and have been reported to interact with, and increase the opening of, the mitochondrial voltagedependent anion channel (VDAC), which leads to the loss in membrane potential and the release of cytochrome-c (Shi et al., 2003).

Bad (Bcl-2-associated death promoter) is a member of the BH3-only subfamily of the Bcl-2 family. Bad is dephosphorylated and activated to form a heterodimer with antiapoptotic proteins $\mathrm{Bcl}-2$ and $\mathrm{Bcl}-\mathrm{xL}$ and prevent them from avoiding apoptosis. Free radicals can initiate a chain of reactions involved in modulation of signal transduction pathways, including regulation of tissue growth and apoptosis. Studies have shown that the redox status of the cell, resulting from an accumulation of Reactive Oxygen Species (ROS) and a decrease of antioxidant levels, is involved in inducing apoptotic cell death (Hockenbery et al., 1993) and GSH presumably plays a critical role in regulating apoptosis by influencing the redox status (Boggs et al., 1998). Loven (1988) suspected that free radical production may be one mechanism by which heat shock alters cellular function.

Cellular exposure to heat stress increases the production of ROS, thereby promoting cellular oxidation events (Skibba et al., 1991; Sikka et al., 1995; Ikeda et al., 1999; Kim et al., 2005) and also associated cellular hyperthermia (Skibba and Stadnicka, 1986; Malayer et al., 1990; Ando et al., 1997). Incorporation of antioxidants has been reported to moderate the deleterious effects of heat-stress on oocytes (Hansen, 2009; Ahmed et al., 2016) seemingly due to the generation of reactive oxygen species. This has also been amply documented in cattle with retinol invitro (Lawrence et al., 2004) as well as in mice with epigallocatechingallate (EGCG) invivo during the preovulatory period (Roth et al., 2008). Various studies suggest the role of antioxidants in mitigating the deleterious effects of ROS as an inducer of apoptosis.

The present study was undertaken to evaluate the expression of pro-apoptotic genes $\mathrm{Bad}$ and Bax and the anti-apoptotic Bcl-2 gene by bovine oocytes during maturation under heat stress $\left(41^{\circ} \mathrm{C}\right)$. Simultaneously, two candidate antioxidants viz. melatonin and zinc were added to the oocyte maturation medium (OMM) to evaluate if they had any amelioration effect, while influencing the expression of the apoptotic genes. 
Materials and Methods

\section{Collection of oocytes and in vitro Maturation (IVM)}

Aspiration media and oocyte maturation media (OMM) were prepared according to Dutta et al., 2013. Ovaries from cows were collected from local abattoirs immediately post-slaughter and transported to the laboratory in sterile pre-warmed normal saline containing antibiotic (Penicillin G @ $0.06 \mathrm{~g} / 1000 \mathrm{ml}$ ) at $37^{\circ} \mathrm{C}$. The connective tissue covering the ovaries were removed, and washed thrice with normal saline containing antibiotic.

Cumulus oocyte complexes (COCs) were collected by aspiration of surface follicles with a sterile 18 gauge needle attached to a 10 $\mathrm{ml}$ syringe containing the aspiration medium. Only follicles of 2-8 $\mathrm{mm}$ diameter or greater were selected amongst those present on the surface. The COCs were separated from the debris and picked individually under a stereozoom microscope on to another petridish with washing medium and graded according to Hafez and Hafez, 2000, while only Grade 'A' and ' $\mathrm{B}$ ' COCs were selected for in vitro maturation. OMM droplets were prepared by taking $50 \mu \mathrm{l}$ of in vitro $\mathrm{OMM}$ in a $35 \mathrm{~mm}$ petridish and covered with sterile $0.2 \mu \mathrm{m}$ filtered mineral oil and incubated for 1 hour in a $\mathrm{CO}_{2}$ incubator at $38.5^{\circ} \mathrm{C}$ with $5 \% \mathrm{CO}_{2}$ and humidified air. Selected COCs (A and B grade) were washed six times in washing media and twice in OMM media. Approximately 10-12 washed COCs were then transferred into each OMM droplet for maturation and incubated for 24 hours in a $\mathrm{CO}_{2}$ incubator at $38.5^{\circ} \mathrm{C}$ with $5 \% \mathrm{CO}_{2}$ and humidified air. For heat stress studies COCs were exposed to $41^{\circ} \mathrm{C}$ temperature during the first $12 \mathrm{hrs}$ of in vitro maturation (IVM) as described by Roth and Hansen (Roth and Hansen, 2004).

\section{Antioxidant supplementation}

Oocyte Maturation Medium (OMM) was supplemented either with $1 \mathrm{nM}$ melatonin (Sigma, India) modified from Jang et al., 2005 and prepared according to Farahavar et al., 2010 ; or $1.5 \mu \mathrm{g} / \mathrm{ml}(\sim 11 \mu \mathrm{mM})$ Zinc modified from Picco et al., 2010 as zinc chloride (Sigma, India).

\section{Experimental design}

In the experiment, bovine oocytes were divided into 4 groups and Group II, III, IV was matured under heat-stress at $41^{\circ} \mathrm{C}$. Moreover, group III and IV were supplemented with antioxidant melatonin and zinc respectively, while Group II served as antioxidant control and was matured with OMM alone. Group I served as control and was matured without heat-stress $\left(38.5^{\circ} \mathrm{C}\right)$ and antioxidant supplementation.

\section{Isolation of total RNA}

Total RNA from oocytes was isolated using a commercially available kit (Promega, SV Total RNA Isolation System, \#Z3100) according to manufacturer's instructions.

\section{cDNA synthesis and quantitative real time PCR (qPCR)}

The first strand cDNA was synthesized from the isolated total RNA. Reverse transcription of the RNA extracted from oocytes was performed using the following reagents-(a) RevertAid $^{\mathrm{TM}} \mathrm{M}-\mathrm{MuL}$ Reverse Transcriptase (Thermo Scientific, \#EP0441), (b) Ribolock (Ribonuclease inhibitor) $(40 \mathrm{u} / \mu \mathrm{L})$ (Thermo Scientific, \#EO0381), (c) $10 \mathrm{mM}$ dNTP mix (Thermo Scientific, \#R0192) and (d) Random hexamer $(0.2 \mu \mathrm{g} / \mu \mathrm{l}) \quad$ (Thermo Scientific, \#SO142). Reverse transcription reaction was carried out with two-step PCR cycling condition at $70^{\circ} \mathrm{C}$ for $5 \mathrm{~min}, 25^{\circ} \mathrm{C}$ for $10 \mathrm{~min}$ 
$\left(1^{\text {st }}\right.$ cycling condition) and $25^{\circ} \mathrm{C}$ for 5 min, $42^{\circ} \mathrm{C}$ for $60 \mathrm{~min}$ and $70^{\circ} \mathrm{C}\left(2^{\text {nd }}\right.$ cycling condition) in a thermal cycler. Primers for $B c l-2, B a d, B a x$ and reference gene (GAPDH) were used (Table 1). The yield of total RNA and cDNA were routinely checked to be pure spectrophotometrically (Thermo, NanoDrop 1000). For total nucleic acid yield, sample concentration was expressed in $n \mu / \mu l$ as estimated at $260 \mathrm{~nm}$. The purity was estimated from the relative absorbance at 230, 260 and $280 \mathrm{~nm}$. The A260/A280 ratio of absorbance was used to assess the purity of DNA and RNA. A ratio of $\sim 1.8$ was generally accepted as "pure" for DNA; a ratio of $\sim 2.0$ was generally accepted as "pure" for RNA. The A260/A230 ratio of sample absorbance was also used as secondary measure of nucleic acid purity which were often higher $(1.8-2.2)$ for "pure" nucleic acid than the respective 260/280 values.

The real time PCR reaction was carried out in Applied Biosystems, StepOnePlus ${ }^{\mathrm{TM}}$ RealTime PCR System with $3.0 \mu \mathrm{l}$ of c DNA template, $10.0 \mu \mathrm{l}$ of Maxima SYBR green qPCR master mix and volume of $B c l-2, B a d$, Bax and GAPDH sequence specific forward and reverse primers $(5 \mathrm{pmol} / \mu \mathrm{l})$ were used and final volume of $20 \mu \mathrm{l}$ was made with nuclease free water (Table 2). The realtime PCR program (Table 3) consisted of initial heating at $95^{\circ} \mathrm{C}$ for $10 \mathrm{~min}$ followed by $95^{\circ} \mathrm{C}$ for $15 \mathrm{sec}$ and samples were amplified for 40 cycles $\left(60^{\circ} \mathrm{C}\right.$ for $45 \mathrm{sec}$ and $95^{\circ} \mathrm{C}$ for $15 \mathrm{sec}$. The melt curve stage for one more cycle at $60^{\circ} \mathrm{C}$ for $1 \mathrm{~min}$ and $95^{\circ} \mathrm{C}$ for $15 \mathrm{sec}$.

The relative quantification of target genes expression was calculated using $2^{-\Delta \Delta \mathrm{Ct}}$. The threshold cycle $(\mathrm{Ct})$ values were based on triplicate measurements and each experiment was repeated twice. The quantification values obtained for target genes in control were used for calibration and were arbitrarily set to 1 and 0 for linear and $\log$ graph types respectively. The data analysis was carried out by StepOne ${ }^{\circledR}$ Plus software v2.2.2 using the $\mathrm{Ct}$ method employing GAPDH as reference gene for normalization $[\Delta \mathrm{CT}=\mathrm{Ct}$ of target gene $(\Delta \mathrm{CTT})$ - Ct of reference gene $(\triangle \mathrm{CTR})]$. The threshold line was assigned to all PCR reactions and the cut-off $\mathrm{C}_{\mathrm{T}}$ value was taken after 40 cycles. To confirm the specificity of each product, melt curve analysis was conducted.

The experimentation was cleared by Institutional Animal Ethics Committee (IAEC) under CPCSEA.

\section{Results and Discussion}

\section{Verification of cDNA synthesis}

After cDNA synthesis, PCR was performed for confirmation of product size of primers by electrophoresis on 2\% agarose gel and also in $12 \%$ SDS PAGE (Figure 1).

Screening the transcription profile of $\mathrm{Bcl}-2$, $B a d$ and Bax genes by qPCR showed that they were expressed in oocytes matured in different antioxidant supplemented and nonsupplemented OMM with heat stress as well as non-supplemented OMM without heat stress. The relative quantification (RQ) values of Bcl-2, Bad and Bax gene mRNA expression are presented in Figure 2. Melt curve analysis also gave a single peak in positive samples for each of the target products suggesting a single size product.

The relative quantification (RQ) values of $\mathrm{Bcl}-2$ indicated that the expression of $\mathrm{Bcl}-2$ gene was up-regulated in oocytes that were heat-stressed in non-supplemented OMM when compared with oocytes under normal temperature and non-supplemented control. RQ values for Bad expression was upregulated only in non-supplemented heatstressed OMM and down-regulated in 
melatonin and zinc supplemented OMM. RQ values for Bax was down regulated in zinc and melatonin supplemented OMM. In heat stressed non-supplemented group there is down-regulation of $B a x$ expression than reference control.

\section{Heat stress and non-supplemented group}

In the present study, it is speculated that the existence of pro-apoptotic signals due to heat stress would probably lead to the elevation of Bad mRNA to counter the pro-survival elevated expression of $B c l-2$. This would result in increased translation and formation of heterodimers between dephosphorylated $\mathrm{Bad}$ and $\mathrm{Bcl}-2$, thereby shifting the balance towards apoptosis by leaving the Bax proapoptotic protein free. Yang and Rajamahendran (2002) reported that the expression of Bax was found in all types of oocytes and embryos, with the highest expression in the denuded oocytes. Similarly, a high level of Bax has also been observed in degenerating oocytes (Felici et al., 1999) indicating spontaneous apoptosis, and that good quality oocytes are resistant to apoptosis and are Bax deficient (Perez et al., 1997). Reportedly, Bax is also significantly altered by the modification of culture conditions, or oocytes with different developmental competence (Nemcova et al., 2006). Furthermore, expression of Bax is observed to be higher in blastocysts cultivated in a synthetic oviduct medium (SOF) than in those cultured in ovine oviduct or in vivo (Lonergan et al., 2003). Similarly, expression of Bax mRNA was observed to be significantly higher $(\mathrm{p}<0.05)$ for the buffalo oocytes matured at higher temperatures (40.5 and $41.5^{\circ} \mathrm{C}$ ) at both the incubations (12 and $24 \mathrm{~h}$ ) compared to control, while mRNA expression of $\mathrm{Bcl}-2$ decreased significantly $(\mathrm{p}<0.05)$ in the treatment groups compared to control (Ashraf et al., 2014). Bax/Bcl-2 ratio has also been found to be almost six times higher in buffalo oocytes immediately after the heat stress that could lead to apoptosis (Singh, 2015). We further observed that elevated $\mathrm{Bad}$ profiles were associated only in nonsupplemented control group and not in any of the oocytes supplemented with antioxidant melatonin and zinc.

\section{Heat stress and melatonin}

In the present study there was a down regulation of both Bax and Bad pro-apoptotic transcripts. $B c l-2$ decreased expression was also noticed by us and probably was due to the associated decrease of the pro-apoptotic transcripts. An alternative but not mutually exclusive hypothesis suggested by Hildeman et al., (2003), is that ROS act to downregulate endogenous $\mathrm{Bcl}-2$ levels within cells, and because levels of $\mathrm{Bcl}-2$ within cells are critical to anti-apoptotic activity, decreasing $\mathrm{Bcl}-2$ could be a mechanism to sensitize cells to apoptosis. By detoxifying ROS, antioxidants (i.e. melatonin, as in this case) may therefore subsequently reverse the ROSinduced decline in $\mathrm{Bcl}-2$ and prevent apoptosis. The entry of oocytes into a state of meiotic arrest may also be associated with reduced transcription and translational activities as observed in all three $\mathrm{Bcl}-2, \mathrm{Bad}$ and Bax transcripts under investigation.

\section{Heat stress and zinc}

The supplementation of zinc in the media brought about a down-regulation of both proapoptotic transcripts Bad and Bax exceeding the levels induced by melatonin. However, the precise mechanism of zinc as an antioxidant is unclear. An alternate credible explanation is the importance of zinc in inducing meiotic arrest of the oocytes throughout the entire oocyte maturation process during the first (Kong et al., 2012) and second (Kim et al., 2010) meiotic arrest points. 
Table.1 Primers used for expression and quantification studies of Bcl-2, Bax, Bad and GAPDH using SYBR ${ }^{\circ}$ Green based qPCR

\begin{tabular}{|c|c|c|c|c|}
\hline Gene primer sequence & $\begin{array}{l}\text { Annealing } \\
\text { temp. }\end{array}$ & $\begin{array}{l}\text { Product } \\
\text { size }\end{array}$ & $\begin{array}{l}\text { Accession } \\
\text { No. }\end{array}$ & Reference \\
\hline \multicolumn{5}{|l|}{ Bcl-2 } \\
\hline TCGTGGCCTTCTTTGAGTTC & \multirow[t]{2}{*}{60} & \multirow[t]{2}{*}{109} & \multirow{2}{*}{$\begin{array}{l}\text { XM_5869 } \\
76.4\end{array}$} & \multirow{2}{*}{$\begin{array}{l}\text { Fear and } \\
\text { Hansen (2011) }\end{array}$} \\
\hline CGGTTCAGGTACTCGGTCAT & & & & \\
\hline \multicolumn{5}{|l|}{ Bax } \\
\hline CTCCCCGAGAGGTCTTTTTC & \multirow[t]{2}{*}{60} & \multirow[t]{2}{*}{176} & \multirow{2}{*}{$\begin{array}{l}\text { NM_1738 } \\
94.1\end{array}$} & \multirow{2}{*}{$\begin{array}{l}\text { Fear and } \\
\text { Hansen (2011) }\end{array}$} \\
\hline TCGAAGGAAGTCCAATGTCC & & & & \\
\hline \multicolumn{5}{|l|}{ Bad } \\
\hline CTTTTCTGCAGGCCTTATGC & \multirow[t]{2}{*}{59} & \multirow[t]{2}{*}{151} & \multirow{2}{*}{$\begin{array}{l}\text { NM_0010 } \\
35459.1\end{array}$} & \multirow{2}{*}{$\begin{array}{l}\text { Fear and } \\
\text { Hansen (2011) }\end{array}$} \\
\hline GGTAAGGGCGGAAAAACTTC & & & & \\
\hline \multicolumn{5}{|c|}{ GAPDH (Glyceraldehyde-3-phosphate dehydrogenase) } \\
\hline $\begin{array}{l}\text { AAGGTCGGAGTGAACGGATT } \\
\text { C }\end{array}$ & \multirow[t]{2}{*}{60} & \multirow[t]{2}{*}{170} & \multirow[t]{2}{*}{-} & \multirow[t]{2}{*}{$\begin{array}{l}\text { Hashem et al. } \\
\text { (2013) }\end{array}$} \\
\hline $\begin{array}{l}\text { TTGACTGTGCCGTTGAACTT } \\
\text { G }\end{array}$ & & & & \\
\hline
\end{tabular}

Table. 2 Components of $\mathrm{qPCR}$ reaction mixture

\begin{tabular}{|c|c|c|}
\hline Components & $\begin{array}{c}\text { Reaction } \\
\text { mixture }\end{array}$ & $\begin{array}{l}\text { Non-Template } \\
\text { Control (NTC) }\end{array}$ \\
\hline Maxima SYBR green/ROX qPCR Master Mix (2X) & $10.0 \mu \mathrm{l}$ & $10.0 \mu \mathrm{l}$ \\
\hline Forward primer $(5 \mathrm{pmol} / \mu \mathrm{l})$ & $0.50 \mu 1$ & $0.50 \mu \mathrm{l}$ \\
\hline Reverse primer $(5 \mathrm{pmol} / \mu \mathrm{l})$ & $0.50 \mu \mathrm{l}$ & $0.50 \mu \mathrm{l}$ \\
\hline cDNA template & $3.0 \mu 1$ & - \\
\hline Nuclease free water & $6.0 \mu 1$ & $9.0 \mu 1$ \\
\hline Total reaction volume & $20.0 \mu \mathrm{l}$ & $20.0 \mu \mathrm{l}$ \\
\hline
\end{tabular}

Table.3 Conditions for SYBR® Green based qPCR reaction

\begin{tabular}{|l|c|c|c|}
\hline Step & Temperature $\left.\mathbf{(}^{\mathbf{0}} \mathbf{C}\right)$ & Duration & Cycles \\
\hline Initial Denaturation & 95 & $10 \mathrm{~min}$ & HOLD \\
\hline Denaturation & 95 & $15 \mathrm{sec}$ & 40 \\
\hline Anneal/ Extend & 60 & $45 \mathrm{sec}$ & \\
\hline \multirow{2}{*}{ Melt curve stage } & 95 & $15 \mathrm{sec}$ & 1 \\
\cline { 2 - 3 } & 60 & $1 \mathrm{~min}$ & \\
\cline { 2 - 3 } & 95 & $15 \mathrm{sec}$ & \\
\hline
\end{tabular}


Fig.1 Gel electrophoresis of amplicons generated by q-PCR showing specific bands for apoptotic genes Bcl-2, Bad, Bax and reference gene GAPDH

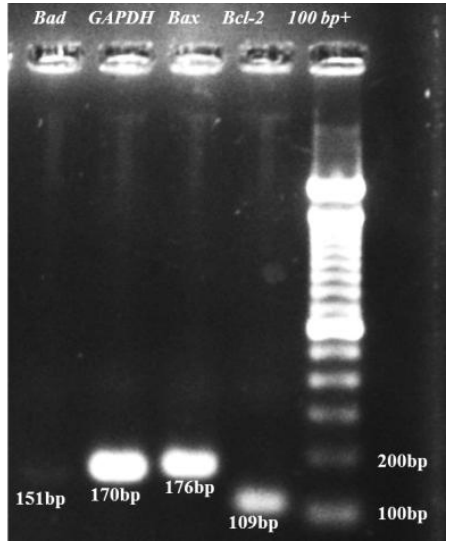

$\underline{2 \% \text { Agarose }}$

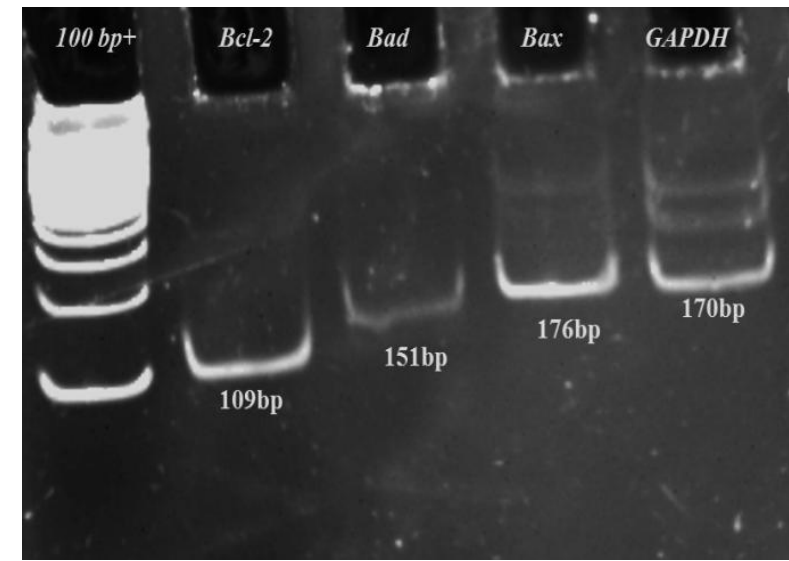

$12 \%$ Polyacrylamide gel electrophoresis (PAGE)

Fig.2 Relative quantification (RQ) by q-PCR of Bcl-2, Bad and Bax mRNA expression in bovine oocytes matured in non-supplemented, and antioxidant melatonin, and zinc supplement Oocyte Maturation Medium (OMM) matured under elevated temperatures $\left(41^{\circ} \mathrm{C}\right)$.

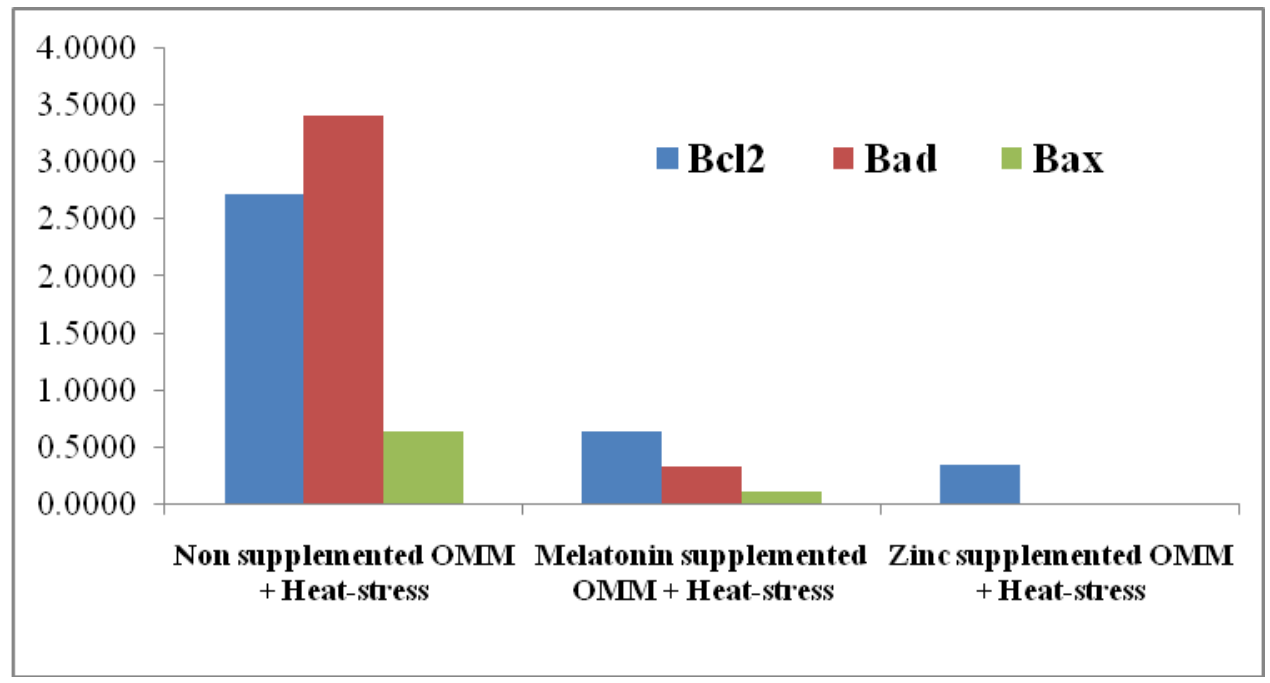

It may be reasoned that the entry of the oocytes in a state of meiotic arrest could bring about a decrease in transcriptional activities. And since, the induction of meiotic arrest is profoundly modulated by zinc, it is reasonable that the transcriptional activities be more affected. Similarly, barely detectable $\mathrm{Bcl}-2$ has been described in oocytes entering into meiosis without changing its expression during the stage of meiotic prophase-I (Felici et al., 1999). Jeon et al., (2014) observed that treatment with adequate zinc concentrations during IVM improved the developmental potential of porcine embryos by regulating the intracellular GSH concentration, the ROS level and transcription factor expression, and transcript levels of Bax were decreased in zinc-treated cumulus cells and oocytes, whereas, $B c l-2$ transcript levels were significantly higher in zinc-treated IVF blastocysts. It is postulated that supplementation with zinc probably induced 
early maturation changes in the oocyte and induced an early meiotic arrest, which was associated with a sharp decline in all apoptosis modulator transcripts. From the present study, it may be concluded that Bax expression may be lower in good quality oocytes, as only good quality eggs were selected for the experimentation. Elevated Bad profiles were associated only in nonsupplemented control group and not in any of the oocytes supplemented with antioxidants melatonin or zinc. The ameliorating effects of antioxidants resulting in the decreased expression of pro-apoptotic genes, verifies an underlying oxidative stress mechanism for apoptosis, and that their incorporation in invitro medium is beneficial during heat stress. The meiotic arrest after maturation may be involved in an inhibition of transcription activity of the oocyte which was seen in expression profiles of apoptosis modulator genes. Supplementation with zinc probably induced early maturation changes in the oocyte and induced an early meiotic arrest, which was associated with a sharp decline in all apoptosis modulator transcripts.

\section{Acknowledgement}

The experiment was part of PhD thesis work by the first author who would like to thank the Dean and State Biotech Hub, College of Veterinary Science, Assam Agricultural University, Guwahati-781022, Assam, India for providing necessary facilities. All the authors have contributed to the work and/or preparation of the manuscript.

\section{References}

Ahmed, J.A., Dutta, D. and Nashiruddullah, N. (2016). Comparative efficacy of antioxidant retinol, melatonin, and zinc during in vitro maturation of bovine oocytes under induced heat stress. Turk. J. Vet. Anim. Sci., 40: 365-373.

Ando, M., Katagiri, K., Yamamoto, S.,
Wakamatsu, K., Kawahara, I., Asanuma, S., Usuda, M. and Sasaki, K. (1997). Agerelated effects of heat stress on protective enzymes for peroxides and microsomal monooxygenase in rat liver. Environ. Hlth. Perspect., 195: 727-733.

Ashraf, S., Shah, S.M., Saini, N., Dhanda,S., Kumar, A., Goud, T.S., Singh, M.K., Chauhan. M.S. and Upadhyay, R.C. (2014). Developmental competence and expression pattern of bubaline (Bubalus bubalis) oocytes subjected to elevated temperatures during meiotic maturation in vitro. J. Assist. Reprod. Genet., 31(10): 1349-1360.

Boggs, S.E., McCormick, T.S. and Lapetina, E.G. (1998). Glutathione levels determine apoptosis in macrophages. Biochem. Biophys. Res. Commun., 247: 229-233.

Boumela, I., Assou, S., Aouacheria, A., Haouzi, D., Dechaud, H., De Vos, J., Handyside, A. and Hamamah, S. (2011). Involvement of Bcl-2 family members in the regulation of human oocyte and early embryo survival and death: gene expression and beyond. Reprod., 141: 549-561.

De Felici, MD., Carlo, A.D., Pesce, M., Lona, S., Farrace, M.G. and Piacentini, M. (1999). Bcl-2 and Bax regulation of apoptosis in germ cells during prenatal oogenesis in the mouse embryo. Cell Death Differ., 6: 908-915.

Dutta, D.J., Dev, H., and Raj, H. (2013). In vitro blastocyst development of post-thaw vitrified bovine oocytes. Vet World, 6: 730-733.

Farahavar, A., Shahne, A.A., Kohram, H. and Vahedi, V. (2010). Effect of melatonin on in vitro maturation of bovine oocytes. Afr. J. Biotechnol., 9: 2579-2583.

Fear, J.M. and Hansen, P.J. (2011). Developmental changes in expression of genes involved in regulation of apoptosis in the bovine preimplantation embryo. Biol. Reprod., 84: 43-51.

Felici, M.D., Carlo, A.D., Pesce, M., Iona, S., Farrace, M.G. and Piacentini, M. (1999). $B c l-2$ and Bax regulation of apoptosis in germ cells during prenatal oogenesis in 
the mouse embryo. Cell Death Differ., 6(9): 908-915.

Gross, A., McDonnell, J.M. and Korsmeyer, S.J. (1999). BCL-2 family members and the mitochondria in apoptosis. Genes Dev., 13: 1899-1911.

Hafez, E.S.E. and Hafez, B. (2000). Assisted reproductive technology. Part VI. In: Reproduction in Farm Animals. $7^{\text {th }}$ Edition. Wiley.

Hansen, P.J. (2009). Effects of heat stress on mammalian reproduction. Phil. Trans. $R$. Soc. B., 364: 3341-3350.

Hashem, M.A., Hossain, M.M., MohammadiSangcheshmeh, A., Cinar, U., Rings, F., Schellander, K., Tesfaye, D. and Hoelker, M. (2013). Differential response of IVP, parthenogenetic and nuclear transfer derived bovine embryos upon environmental heat stress-implications for expression of autosomal and X-linked genes. Bang. J. Anim. Sci., 42(1): 1-10.

Hildeman, D.A., Mitchell, T., Aronow, B., Wojciechowski, S., Kappler, J. and Marrack, P. (2003). Control of $\mathrm{Bcl}-2$ expression by reactive oxygen species. PNAS, 100: 15035-15040.

Hockenbery, D.M., Oltvai, Z.N., Yin, X.M., Milliman, C.L. and Korsmeyer, S.J. (1993). Bcl-2 functions in an antioxidant pathway to prevent apoptosis. Cell, 75: 241-251.

Ikeda, M., Kodama, H., Fukuda, J., Shimizu, Y., Murata, M., Kumagai, J. and Tanaka, T. (1999). Role of radical oxygen species in rat testicular germ cell apoptosis induced by heat stress. Biol. Reprod., 61: 393-399.

Jang, H.Y., Kong, H.S., Choi, K.D., Jeon, G.J., Yang, B.K., Lee, C.K. and Lee, H.K. (2005). Effects of melatonin on gene expression of IVM / IVF porcine embryos. Asian-Aust. J. Anim. Sci., 18: 17-21.

Jeon, Y., Yoon, J.D., Cai, L., Hwang, S.U., Kim, E., Zheng, Z., Lee, E., Kim, D.Y. and Hyun, S.H. (2014). Supplementation of zinc on oocyte in vitro maturation improves preimplatation embryonic development in pigs. Theriogenology, 82(6): 866-874.

Kim, A.M., Vogt, S., O'Halloran, T.V. and Woodruff, T.K. (2010). Zinc availability regulates exit from meiosis in maturing mammalian oocytes. Nature Chem. Biol., 6: 674-681.

Kim, H.J., Kang, B.S. and Park, J.W. (2005). Cellular defence against heat shockinduced oxidative damage by mitochondrial NADP(+)-dependant isocitrate dehydrogenase. Free Radical Res., 39(4): 441-448.

Kong, B.Y., Bernhardt, M.L., Kim, A.M., O'Halloran, T.V. and Woodruff, T.K. (2012). Zinc maintains prophase I arrest in mouse oocytes through regulation of the MOS-MAPK pathway. Biol. Reprod., 87: $1-12$.

Lawrence, J.L., Payton, R.R., Godkin, J.D., Saxton, A.M., Schrick, F.N. and Edwards, J.L. (2004). Retinol improves development of bovine oocytes compromised by heat stress during maturation. J. Dairy Sci., 87(8): 24492454.

Li, H.J., Liu, D.J., Cang, M., Wang, L.M., Jin, M.Z., Ma, Y.Z. and Shorgan, B. (2009). Early apoptosis is associated with improved developmental potential in bovine oocytes. Anim. Reprod. Sci., 114(1-3): 89-98.

Lonergan, P., Gutierrez-Adan, A., Rizos, D., Pintado, B., de la Fuente, J. and Boland, M.P. (2003). Relative messenger RNA abundance in bovine oocytes collected in vitro or in vivo before and $20 \mathrm{~h}$ after the preovulatory luteinizing hormone surge. Mol. Reprod. Dev., 66: 297-305.

Loven, D. P. (1988). A role for reduced oxygen species in heat induced cell killing and the induction of thermotolerance. Med. Hypotheses., 26: 39-50.

Malayer, J.R., Hansen, P.J., Gross, T.S. and Thatcher, W.W. (1990). Regulation of heat shock-induced alterations in release of prostaglandins by the uterine endometrium of cows. Theriogenology, 34: 219-230. 
Nemcova, L., Machatkova, M., Hanzalova, K., Horakova, J. and Kanka, J. (2006). Gene expression in bovine embryos derived from oocytes with different developmental competence collected at the defined follicular developmental stage. Theriogenology, 65: 1254-1264.

Perez, G.I., Knudson, C.M., Leykin, L., Korsmeyer, S.J. and Tilly, J.L. (1997). Apoptosis-associated signalling pathways are required for chemotherapy-mediated female germ cell destruction. Nature Med., 3: 1228-1232.

Picco, S.J., Anchordoquy, J.M., de Matos, D.G., Anchordoquy, J.P., Seoane, A., Mattioli, G.A., Errecalde, A.L. and Furnus, C.C. (2010). Effect of increasing zinc sulphate concentration during in vitro maturation of bovine oocytes. Theriogenology, 74: 1141-1148.

Reed, J.C., Zha, H., Aime-Sempe, C., Takayama, S. and Wang, H.G. (1996). Structure-function analysis of $\mathrm{Bcl}-2$ family proteins. Regulators of programmed cell death. Adv. Exp. Med. Biol., 406: 99-112.

Roth, Z. and Hansen, P.J. (2004). Involvement of apoptosis in disruption of developmental competence of bovine oocytes by heat shock during maturation. Biol. Reprod., 71: 1898-1906.

Roth, Z., Aroyo, A., Yavin, S. and Arav, A. (2008). The antioxidant epigallocatechin gallate (EGCG) moderates the deleterious effects of maternal hyperthermia on follicle enclosed oocytes in mice. Theriogenology, 70: 887-897.
Shi, Y., Chen, J., Weng, C., Chen, R., Zheng, Y., Chen, Q. and Tang, H. (2003). Identification of the protein-protein contact site and interaction mode of human VDAC1 with Bcl-2 family proteins. Biochem. Biophys. Res. Commun., 305: 989-996.

Sikka, S.C., Rajasekaran, M. and Hellstrom, W.J.G. (1995). Role of oxidative stress and antioxidants in male infertility. $J$. Androl., 16: 464-468.

Singh, D. (2015). Gene expression profiling of buffalo preimplantation embryos produced under in-vitro heat stress conditions. Ph.D. thesis submitted to ICAR-National Dairy Research Institute, India.

Skibba, J.L. and Stadnicka, A. (1986). Xanthine oxidase (XO) activity at hyperthermic temperatures as a source of free radicals. Proc. Am. Assn. Cancer Res., 27: 400.

Skibba, J.L., Powers, R.H., Stadnicka, A., Cullinane, D.W., Almargo, U.A. and Kalbfleisch, J.H. (1991). Oxidative stress as a precursor to the irreversible hepatocellular injury caused by hyperthermia. Int. J. Hyperther., 7(5): 749-761.

Yang, M.Y. and Rajamahendran, R. (2002). Expression of Bcl-2 and Bax proteins in relation to quality of bovine oocytes and embryos produced in-vitro. Anim. Reprod. Sci., 70: 159-169

Youle, R.J. and Strasser, A. (2008). The BCL-2 protein family: opposing activities that mediate cell death. Nature Rev. Mol. Cell Biol., 9: 47-59.

\section{How to cite this article:}

Jafrin Ara Ahmed, Nawab Nashiruddullah, Devojyoti Dutta, Iftikar Hussain, Anubha Baruah and Arup Dutta. 2019. Effect of Heat Stress and Amelioration by Antioxidants on Expression Profile of Pro- and Anti-Apoptotic Genes in in vitro Matured Bovine Oocytes. Int.J.Curr.Microbiol.App.Sci. 8(02): 2394-2403. doi: https://doi.org/10.20546/ijcmas.2019.802.279 